\title{
Development of Learning Tools Based on Malay Culture and Contextual Approach to Improve Visual Representation Thinking Achievement of MTs Negeri Tanjung Pura Students
}

\author{
Joko Mariono \\ Education of Mathematic, Post Graduate \\ State University of Medan \\ Medan, Indonesia \\ Corresponding email: jokomariono182@gmail.com
}

\author{
Izwita Dewi \\ Department of MathematicsScience Faculty \\ State University of Medan \\ Medan, Indonesia
}

\author{
Edy Surya \\ Department of Mathematics Science Faculty \\ State University of Medan \\ Medan, Indonesia
}

\begin{abstract}
This research is about the development of learning tools developed using the development model of Thiagarajan Shamel and Shamel. The research aims to find out: (1) Validity of Malay Culture Based Learning and Contextual Approach to Increase Visual Representation Thinking Capabilities of MTs Negeri Tanjung Pura Students. (2) the practicality of Malay Culture Based Learning and Contextual Approach to Improve Visual Representation Thinking Achievement of MTs Negeri Tanjung Pura Students. (a) Student responses to instructional devices, (b) Teacher's response to instructional devices. (3) the effectiveness of Malay Culture Based Learning and Contextual Approach to Increase Visual Representation Thinking Ability of MTs Negeri Tanjung Pura Students. (a) Student achievement reaches $\geq 85 \%$ with mean score of visual thinking representation ability of student reaches 2.67 scale 4. (b) ability of teacher to manage learning reaching minimum criteria good. (c) Criteria for achieving the effectiveness of student activities in learning if the six categories of student activity are met with a 5\% tolerance. (4) Improvement of students' visual thinking representation.
\end{abstract}

Keywords - Development, Learning Tool; CTL; Malay Culture; Visual Thinking Representation .

\section{INTRODUCTION}

The world of education is currently faced with two major problems, namely the low quality of education and inadequate school learning systems. These two things are very contrary to the demands of the globalization era which is marked by AFTA 2005 (Aseans Free Trade Area), MEA 2015 (ASEAN Economic Community) which demands education in order to have knowledge that is responsive to global competition situations and has an understanding to be able to form capable individuals lifetime. The problem of education has always been a topic of conversation that is interesting for the community both in the environment of consumers, teachers, parents, even more among education experts (Hasratuddin, 2015: 19). Things that never run out when we discuss education. The government, through the Act, seeks to improve education. Law Number 20 of 2003 concerning the National Education System, Article 1 number 1 states that education is a conscious and planned effort to realize a learning atmosphere and learning process so that students actively develop their potential to have religious spiritual strength, selfcontrol, personality, intelligence, noble character, and skills needed by him, society, nation and state. It is hoped that this law will improve Indonesian education and increase its international achievements

Teachers as implementers of education are required to have the tools in the implementation of learning to maintain general goals and specific goals so that the education process goes as expected by the government. According to Subanindro (2012: 3) in a simple language learning devices are defined as a set of learning resources arranged in such a way that students and teachers conduct learning activities. While Trianto (2011: 201) states that learning devices are devices used in the learning process. Learning devices function to provide direction for the implementation of learning so that it becomes directed and efficient. The teacher is given the authority to develop the learning tools that will be used. Development is a process, way, deed develops. Learning devices are a set of learning resources that allow students and teachers to carry out learning activities. Development of learning tools is a series of processes or activities carried out to produce a learning tool based on existing development theories (Rohman and Amri, 2013: 207). So the development of learning devices is a process carried out to produce a series of learning tools used by teachers and students in the learning process in the classroom. A set of learning tools that a teacher must prepare in dealing with classroom learning, including: (a) Learning 
Implementation Plans (RPP); (b) Student Books; (c) Teacher's Book (BG); (d) Student Activity Sheet (LAS); (e) Learning ability test. All learning subjects can be developed, mathematics is no exception.

Development of learning tools for mathematics learning becomes necessary because learning mathematics itself is important. Cockroft (Abdurrahman, 2009: 253) states that mathematics needs to be taught to students because: (1) it is always used in all aspects of life, (2) all fields of study require appropriate mathematical skills, (3) is a powerful, short and clearly, (4) can be used to present information in various ways, (5) improve the ability to think logically, accuracy and spatial awareness, (6) provide satisfaction with efforts to solve challenging problems. Cornelius (Abdurrahman, 2009: 253) suggests there are five reasons for the importance of learning mathematics, namely: (1) Mathematics is a clear means of thinking, (2) Mathematics is a means of solving problems in everyday life, (3) Mathematics is a means of knowing patterns of relationships and generalization of experience, (4) Mathematics is a means to develop creativity, (5) Mathematics is a means to increase awareness of cultural development.

Mathematics is formed from human experience in the world empirically. Then the experience is processed in the world of ratios, processed in an analysis with reasoning in the cognitive structure so that mathematical concepts are formed so that the mathematical concepts that are formed are easily understood by others and can be manipulated appropriately, then used mathematical language or notation mathematics that is of global (universal) value. The concept of mathematics is obtained because of the thought process, because logic is the basis for the formation of mathematics. However, in reality mathematics learning in Indonesia is still less competitive in the international world. This was shown by the 2015 PISA (Program for International Student Assessment) study which showed that Indonesia could only be ranked 69th out of 76 countries (Ramadanti: 2016)

Visual representation is an important part in solving mathematical problems. Lavy (Surya, 2013: 113) conveyed the importance of visualization in solving mathematical problems.

Visualization of important roles in thinking development, mathematical comprehension, and the transition thinking of concrete to abstract thinking related to mathematical problem solving.

Visualization has an important role in the development of thinking, mathematical understanding, and the transition of thought to abstract thinking related to mathematical problem solving.

According to Surya (2013) Visual Thinking is an active thought and analytical process to understand, interpret and produce visual messages, the interaction between seeing, imagining, and describing as goals and can be used, such as verbal thinking.

To help students develop visual thinking skills, the teacher must first pay attention to the factors that influence student choice in problem solving methods, and from the processes and roles that students use in visualizing mathematical problem solving. If visualization is the core of mathematical problem solving then it is very important that both teachers and students see the role of visualization and use it to help them in their process of solving problems. If this ability is owned by students, of course students will be easy to solve math problems, especially regarding geometry, but in reality the ability of visual thinking representation of students is still low. This can be seen from observations made by researchers. Researchers raise problems with students of the Tanjung Pura State Islamic Elementary School

The problems raised by students are as follows.

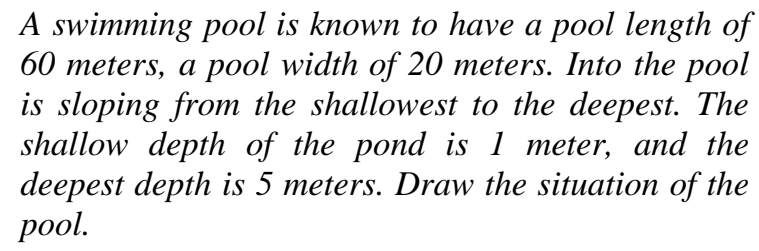

The alternative answers expected by the researcher are as follows.

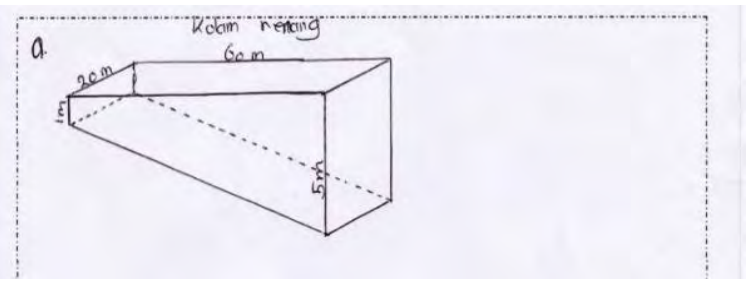

Fig 1. Alternative expected answers

Researchers conducted the first experiment by giving 22 questions to the 9th grade students of MTs Negeri Tanjung pura. This 9th grade student has got the material to build the room in class 8 . However, only 1 student who fulfills and can represent the results of visualization in accordance with the expectations of the researcher and other than that they cannot visualize and represent them correctly. Here's the student's answer.

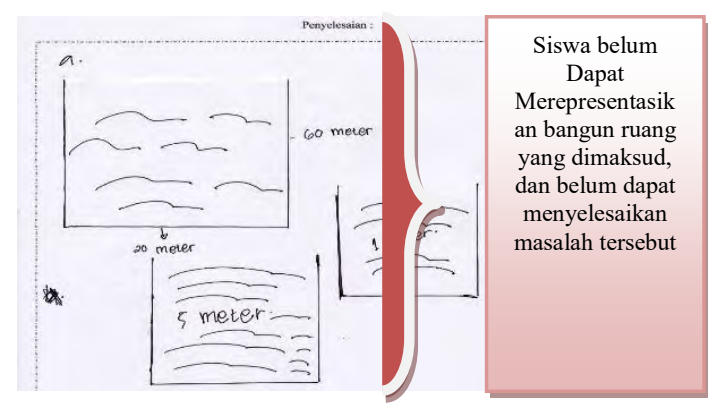

Fig 2 .Student Answers in Visual Thinking Representation questions

From the picture above shows students have not been able to describe the state of the pool referred to in the problem. This student divides into 3 different shapes of flat shapes. Students will be able to solve the problem above if they are able to visualize it in a sketch form and then make a mathematical model. Each individual may vary in visualizing. From here we will know the visualization ability of a student 
at that level. From the experiments conducted by the researcher, it shows the low ability of visual representation of Thinking students

Based on the description above, researchers are interested in conducting a study entitled "Development of Learning Tools Based on Malay Culture and Contextual Approach to Improve the Ability of Visual Thinking Representation of MTs N Tanjung Pura students"

\section{METHOD}

This research includes development research. In this study developed in the form of learning devices namely teacher books, student books, student activity sheets and visual thinking ability ability tests of students. The development process is related to activities at each stage of development. The final product is evaluated based on the product quality aspects specified. Thus, the product of this research is a learning tool based on Malay culture and a contextual approach that is valid, practical and effective. This research was carried out at MTs Negeri Tanjung Pura for the 2017/2018 school year on the Circle material.

This research is divided into two stages, the first stage is the development of learning tools. Development of learning tools which include: (1) the validity of the Teacher's Book; (2) validity of Student Books; (3) LAS validity; (4) the validity of the Thingking Visual Representation ability test instrument. The second stage is the implementation of learning tools that have been validated to see their practicality and effectiveness.

The model of learning device development that will be carried out is the Thiagarajan, Semmel, and Semmel Model, namely the 4-D Model which consists of four stages: the stage of defining, designing, developing and disseminate.

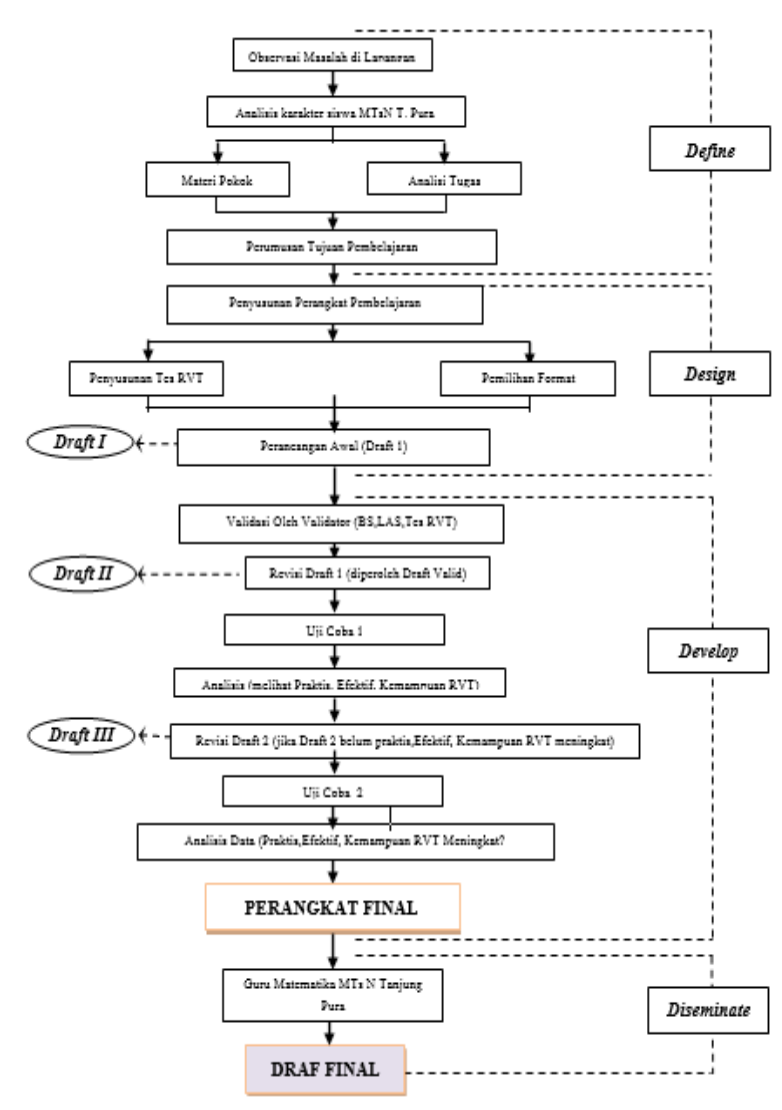

Fig 3. Chart for the development of 4-D model learning tools (Trianto, 2011)

The trial design that will be used in instrument development is One-group pretest-posttest design. As follows :

\begin{tabular}{l}
\hline Tes \\
$\mathrm{T}_{1}$
\end{tabular}

\section{RESULTS AND DISCUSSIONS}

Validity of the device by experts meets valid criteria and can be used in trials. In the first trial, the device was fulfilled practically, but it did not fulfill effectiveness, but there was an increase in the ability of visual thinking representation. In trial 2 , practical, effective criteria and the ability to improve visual thinking representation have been fulfilled.

In line with these results, Novrini (2015) in his research on the development of problem-based learning-oriented learning tools to improve the ability of visual thinking in mathematical problem solving for eighth graders of junior high school obtained positive results in the form of valid, practical and effective devices and obtained students' visual thinking representation enhancement abilities . 
Learning using CTL encourages students to get their own experience. This is in accordance with the theory of the discovery of Bruner's Jerome. Bruner suggested that students should learn through active participation with concepts and principles. So that they are encouraged to gain experience and conduct experiments that allow them to find the principles themselves (Trianto 2009: 38).

Cultural aspects also contribute to the results of research in the form of devices with a cultural context. Which contributes to helping students in understanding contextual problems. Research that also uses culture by Tandaliling (2013) found many aspects of mathematics in culture and used it in understanding mathematics. Vygotsky argues that students build knowledge as a result of students' own thoughts and activities through language. Vygotsky believes that development depends both on biological factors determining elementary memory functions, attention, perception, and response stimulus, social factors are very important for the development of higher mental functions for concept development, logical reasoning, and decision making. (Trianto 2009: 38)

The results of this study are also in line with Surya (2013) who argued that the contextual learning approach (P-CTL) can be applied as an alternative mathematics learning approach to improve visual thinking representation skills and student learning independence and the Contextual Teaching Learning Approach can be applied as an alternative learning approach to enhance Visual Thinking Representation capabilities.

In line with Surya above, Hutagaol (2013) found the results of research showing contextual learning can improve the mathematical representation abilities of junior high school students. Learning outcomes of students who get learning using contextual learning, the ability to represent is better than the learning outcomes of students who use conventional learning.

\section{CONCLUSIONS}

Malay culture-based learning tools and a valid practical and effective contextual approach to improve visual thinking representation skills of Tanjung Pura State MTs students.

\section{REFERENCES}

[1] Abdurrahman, M. 2009. Pendidikan bagi Anak Berkesulitan Belajar. Jakarta: Rineka Cipta

[2] Hasratuddin. 2015. Mengapa Harus Belajar Matematika?. Medan: Perdana Publishing

[3] Ramadanti, R. (2016). Peringkat Pendidikan Indonesia masih Rendah. http://www.pikiran-rakyat.com/pendidikan/2016/06/18/peringkatpendidikan-indonesia-masih-rendah-372187.

[4] Rohman, M dan Amri, S. 2013. Strategi dan Desain Pengembangan Sistem Pembelajaran. Jakarta: Prestasi Pustaka.

[5] Subanindro. 2012. Pengembangan Perangkat Pembelajaran Trigonometri Berorientasikan Kemampuan Penalaran dan Komunikasi Matematik Siswa SMA. Yogyakarta: Prosiding Seminar Nasional Matematika dan Pendidikan Matematika FMIPA UNY.

[6] Surya, E. 2013. Peningkatan Kemampuan Representasi Visual Thinking pada Pemecahan Masalah Matematis dan Kemandirian Belajar Siswa SMP melalui Pembelajaran Kontekstual Universitas Pendidikan Indonesia. Disertasi. Tidak dipublikasikan. Bandung: PPs Universitas Pendidikan Indonesia.

[7] Trianto. 2011. Mendesain Model Pembelajaran Inovatif Progresif. Konsep Landasan , dan Implementasinya pada KTSP. Jakarta: Kencana Prenada Media Group. 